\title{
TUNTUTAN KEADILAN PERSPEKTIF HUKUM ISLAM
}

\author{
Zulkifli \\ Fakultas Syariah IAIN Batusangkar \\ J1. Jenderal Sudirman No. 137, Lima Kaum Batusangkar \\ e-mail: jundjafar@gmail.com
}

\begin{abstract}
The justice is viewed from any perspectives and aspects, it means the justice must be positioned as well as possible depends on the situation and time (when and where). In law empowerment all people bave the same position and they should get their human right. Method which is used in this study was library research. There is a phenomena where the buman right is not found in every buman life, but actually it must reach all factors of the human life which having different and balanced. In deciding the justice for human life, it must be as proportional as possible eventhough the right is not always reaching the same position.
\end{abstract}

Kata Kunci: tuntutan, keadilan, Hukum Islam.

\section{PENDAHULUAN}

$\mathcal{K}$ eadilan merupakan harapan dan dambaan setiap orang dalam tatanan kehidupan sosial. Setiap negara maupun lembaga-lembaga dan organisasi di manapun mempunyai visi dan misi yang sama terhadap keadilan, walaupun persepsi dan konsepsi mereka bisa saja berbeda. Karena dalam pemahaman mereka keadilan sebagai konsep yang relatif dan tolok ukur yang sangat beragam antara satu negara dengan negara lain, dan masing-masing ukuran keadilan itu didefinisikan dan ditetapkan oleh masyarakat sesuai dengan tatanan sosial masyarakat yang bersangkutan. Menurut Majid Khadduri, (1999: 1), sumber keadilan itu ada dua: keadilan positif dan keadilan revelasional. Keadilan positif adalah konsep-konsep produk manusia yang dirumuskan berdasarkan kepentingan-kepentingan individual maupun kepentingan kolektif mereka. Skala keadilan berkembang melalui persetujuan-persetujuan diam-diam maupun tindakan formal, sebagai produk interaksi antara harapan-harapan dan kondisi yang ada. Sedangkan keadilan revelasional adalah bersumber dari Tuhan yang disebut dengan keadilan Ilahi. Keadilan ini dianggap berlaku bagi seluruh manusia, terutama bagi pemeluk agama yang taat. Wahbah Zuhayli (1991: 41), dalam menafsirkan surat Al-Syura ayat 14:

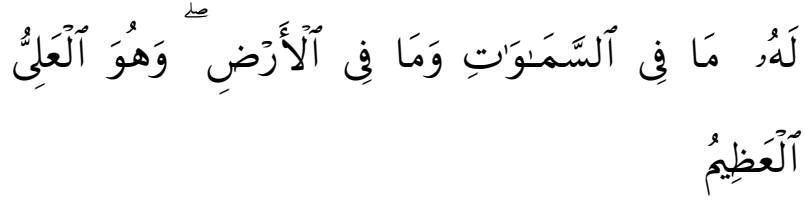

"Milik Allah apa saja yang ada di langit dan di bumi. Dia Maha Tinggi lagi Maha Besar". (Q.S. Al-Syura [42]: 14). 
"Menyatakan keadilan sebagai suatu ajaran universal oleh setiap Rasul, tidak mengalami perubahan dari setiap generasi Rasul dan berakhir pada Muhammad saw. Al-Qur'an dan Al Hadis disepakati sebagai dua sumber pokok dan utama ajaran Muhammad saw, karenanya umat Islam memiliki pegangan yang kuat untuk menggali dan memahami konsep keadilan yang akan diaplikasikan dalam kehidupan individual dan sosial mereka".

Dalam Islam, keadilan disebutkan dengan kata-kata al-Adl, al-Qisth dan alMizan (Muhammad Fuad Abd al-Baqi, 1987: 448-449 dan 544-545). Dalam Ayat Al-Qur`an menurut Muhammad Fuad Abd al-Baqi, untuk menyebut "keadilan" dengan kata al-Adl, dalam berbagai bentuk katanya disebut sebanyak 28 kali, kata al-Qisth dalam berbagai shighahnya disebut sebanyak 27 kali, dan kata alMizan yang mengandung makna yang relevan dengan keduanya disebut 23 kali. Banyaknya ayat Al-Qur`an yang membicarakan keadilan menunjukkan bahwa Allah Swt. adalah sumber keadilan dan memerintahkan menegakkan keadilan di dunia ini kepada para rasul dan seluruh hambaNya. Walaupun tidak ada satupun ayat Al-Qur`an yang secara eksplisit menunjukkan bahwa al-'Adl merupakan sifat Allah, namun banyak ayat yang menerangkan keadilanNya (M. Quraisy Shihab, 2000: 149). Oleh karena itu, dalam kajian al-Asma al-Husna, al-Adl merupakan salah satu asma Allah, tepatnya asma yang ke- 30 dari 99 al-Asma al-Husna itu. Melalui sifat keadilan ini Allah menyuruh untuk lebih meyakini dan mendekatkan diri kepadaNya dan mendorong manusia berakhlak dengan sifat adil Allah itu, dan juga mendorong mereka dengan sungguh-sungguh untuk meraih sifat adil itu, menghiasi diri, dan berakhlak dengan keadilan itu (M. Quraisy Shihab, 2000: 32-33).

Al-Qur`an, memerintahkan agar menegakkan keadilan kepada para Rasul, yang terdapat pada surat al-Hadid (57) ayat 25:

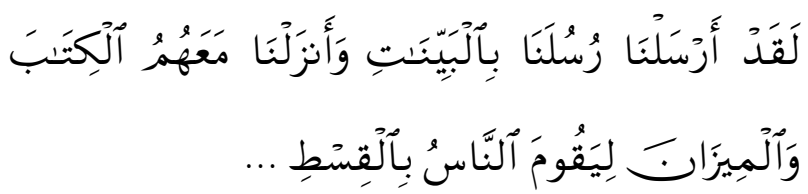

"Sesungguhnya Kami telah mengutus rasul-rasul kami dengan membawa buktibukti yang nyata dan telah kami turunkan bersama mereka al-Kitab dan neraca (keadilan) agar manusia dapat menegakkan keadilan...". (Q.S. Al-Hadid [57]: 25).

Allah SWT juga memerintahkan orangorang mukmin untuk menegakkan keadilan, dan termasuk ke dalam amal shalih serta orang mukmin yang menegakkan keadilan dapat dikategorikan sebagai orang yang telah berupaya meningkatkan kualitas ketakwaan dirinya. Dengan istilah lain, dapat dikatakan bahwa keadilan itu sebagai salah satu indikator yang paling nyata dan dekat dengan ketakwaan. Firman Allah tersebut adalah:

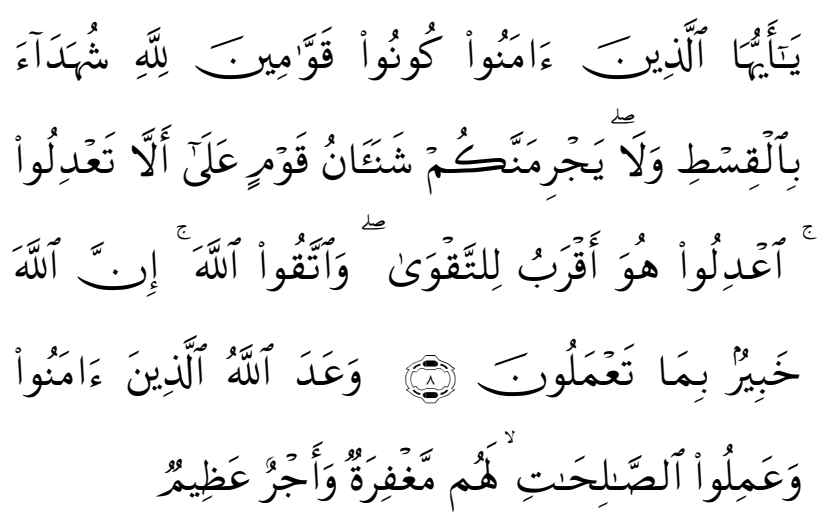

"Hai orang-orang yang beriman, hendaklah kamu menjadi orang-orang yang 
menegakkan (kebenaran) karena Allah, menjadi saksi dengan adil. Dan janganlah sekali-kali kebencianmu terhadap suatu kaum mendorong kamu untuk berlaku tidak adil. Berlaku adillah, karena adil itu lebih dekat dengan takwa dan bertakwalah kepada Allah, sesungguhnya Allah Maha Mengetahui apa yang kamu kerjakan. Allah telah menjanjikan kepada orang-orang yang beriman dan beramal salih, bahwa untuk mereka ampunan dan pahala yang besar". (Q.S. Al-Maidah [5]: 8 dan 9).

Ayat ini memerintahklan orang mukmin menegakkan keadilan di bidang hukum, baik sebagai hakim maupun saksi. Dalam ayat al-An'am (6) ayat 152, Allah juga memerintahkan untuk menegakkan keadilan dalam bentuk ucapan walaupun kepada kaum kerabat:

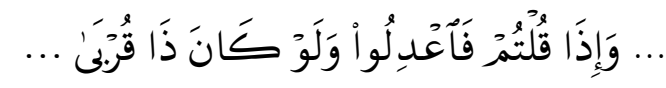

"... Dan apabila kalian berkata, maka berkatalah dengan adil walaupun terhadap kerabat". (Q.S. Al-An'am [6]: 152).

Pada ayat itu juga Allah Swt memerintahkan agar mengelola harta anak yatim dengan baik, dan agar menyempurnakan takaran dan timbangan dengan adil.

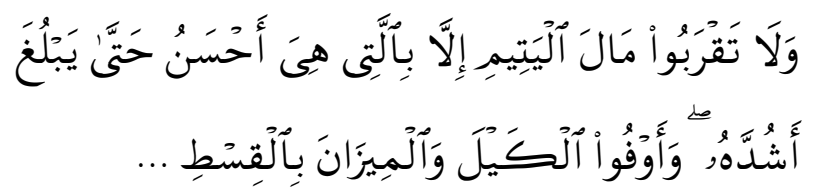

"Dan janganlah kamu dekati harta anak yatim, kecuali dengan cara yang bermanfaat - adil hingga sampai dewasa. Dan sempurnakan takaran dan timbangan dengan adil..."(Q.S. Al-An'am [6]: 152).

Pada hakikatnya, perintah keadilan itu meliputi aspek-aspek kehidupan manusia. Majid Khadduri (1999: 13-14), mengklasifikasikan keadilan ke dalam 8 aspek yang sangat luas: keadilan politik, keadilan teologis, keadilan fillosofis, keadilan etis, keadilan legal, keadilan di antara bangsa-bangsa, dan keadilan sosial. Oleh karena itu, pakar muslim pada umumnya melakukan kajian secara spesifik, seperti Murtadha Muttahari mengkaji keadilan Allah. Para teorilisi politik Islam memasukkan kajian keadilan ke dalam sub kajian politik. M. Dhiauddin Rais yang menulis buku Teori Politik Islam masukkan kajian keadilan ke dalam Prinsip dasar Negara, dan Muhammad Abdul Qadir Abu Fariz, dalam bukunya Sistem Politik Islam, mengistilahkan keadilan sebagai salah satu dari pilar politik Islam, yang empat; yakni kedaulatan Milik Allah, Keadilan dan Persamaan, Ketaatan kepada Pemerintah, dan Syura (musyawarah). Sementara itu, M. Quraisy Shihab dalam buku "Wawasan Islam" juga membahas Keadilan dan Kesejahteraan sebagai salah satu tema kajiannya.

Kajian dalam makalah ini tidak mencakup seluruh aspek keadilan tersebut, hanya diarahkan ke dalam bidang keadilan hukum. Tujuan yang hendak dicapai adalah mengungkapkan bagaimana keadilan hukum itu dalam ajaran Islam.

Adapun metode dalam penulisan ini adalah menghimpun bahan dari berbagai literatur yang relevan kemudian diungkapkan bahasan secara singkat dan menyeluruh. Hasil tulisan ini diharapkan menjadi sumbangan pemikiran kepada para pembaca, sehingga dapat diketahui bagaimana konsep Islam dalam hal keadilan hukum menurut persfektif Islam. 


\section{PEMBAHASAN}

\section{Hakikat Keadilan}

Kata "adil" dalam Bahasa Indonesia, berarti "tidak berat sebelah, tidak memihak, berpihak kepada yang benar, berpegang kepada kebenaran, sepatutnya, dan tidak sewenang-wenang" (Depdikbud, 1990: 6-7). Dalam bahasa Arab, keadilan berarti kesamaan, berasal dari kata kerja (fi'il) 'adala dan mashdarnya adalah al-'adl dan al-idl. Al-'adl untuk menunjukkan sesuatu yang hanya ditangkap oleh bashirah (akal fikiran), dan al-'idl untuk menunjukkan keadilan yang bisa ditangkap oleh panca indera. Contoh yang pertama adalah keadilan di bidang hukum, dan contoh yang kedua antara lain: keadilan dalam timbangan, ukuran, dan hitungan (al-Asfahani, 1972: 336).

M. Quraisy Shihab (1996: 111) mengatakan bahwa keadilan yang berarti kesamaan memberi kesan adanya dua pihak atau lebih, karena kalau hanya satu pihak, tidak akan terjadi adanya persamaan. Makanya kata al-'adl, diungkapkan oleh Al-Qur`an antara lain dengan kata al-'adl, al-qisth, dan al-mizan. Sementara itu, Majid Khadduri (1999: 8) menyebutkan, sinonim kata al-'adl; alqisth, al-qashd, al-istiqamah, al-wasath, alnashib, dan al-hishsha. Kata adil itu mengandung arti: pertama; meluruskan atau duduk lurus, mengamandemen atau mengubah, kedua; melarikan diri, berangkat atau mengelak dari satu jalan yang keliru menuju jalan lain yang benar, ketiga sama atau sepadan atau menyamakan, dan keempat; menyeimbangkan atau mengimbangi, sebanding atau berada dalam suatu keadaan yang seimbang.
Para pakar agama Islam, umumnya, merumuskan keadilan menjadi empat makna (M. Quraisy Shihab, 1996: 114-11 6):

Pertama, adil dalam arti sama. Dengan pengertian, adil, artinya memperlakukan sama antara orang yang satu dengan orang lain. Maksud persamaan di sini adalah persamaan dalam hak. Dalam surat al-Nisa (4): 58 dinyatakan:

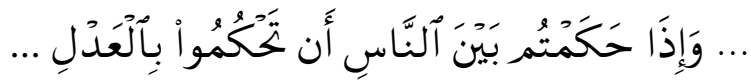

"Apabila kamu sekalian memutuskan perkara di antara manusia, maka kamu sekalian harus memutuskan secara adil". (Q.S. An-Nisa [4]: 58).

Al-adl pada ayat ini, menurut Quraisy Shihab (1996: 114), berarti persamaan, dalam arti bahwa seorang hakim harus memperlakukan sama antara orang-orang yang berperkara, karena perlakuan sama antara para pihak yang berperkara itu merupakan hak mereka. Murtadha Muthahari (1992: 56), dalam pengertian yang sama, mengatakan bahwa keadilan dalam arti persamaan ini bukan berarti menafikan keragaman kalau dikaitkan dengan hak kepemilikan. Persamaan itu harus diberikan kepada orang-orang yang mempunyai hak kepemilikan yang sama. Jika persamaan itu diberikan kepada orang-orang yang mempunyai hak kepemilikan yang berbeda, yang terjadi bukan persamaan tapi kezaliman. Al-Qur`an mengisahkan dua orang berperkara yang datang kepada Nabi Dawud AS untuk mencari keadilan. Orang pertama memiliki sembilan puluh sembilan ekor kambing betina, sedang orang ke dua memiliki seekor. Orang pertama mendesak agar ia diberi pula yang seekor itu agar genap 
menjadi seratus ekor. Keputusan Nabi Dawud AS, bukan membagi kambing itu dengan jumlah yang sama, tapi menyatakan bahwa pihak pertama telah berlaku aniaya terhadap pihak yang kedua.

Kedua, adil dalam arti seimbang yang identik dengan kesesuaian/ proporsional. Keseimbangan tidak mengharuskan persamaan kadar dan sarat bagi semua bagian unit agar seimbang. Petunjuk AlQur`an yang membedakan antara yang satu dengan yang lain, seperti pembedaan laki-laki dan perempuan pada beberapa hak warisan dan persaksian-apabila ditinjau dari sudut pandang keadilanharus dipahami dalam arti keseimbangan, bukan persamaan.

Keadilan dalam pengertian ini menimbulkan keyakinan bahwa Allah yang Maha Bijaksana dan Maha Mengetahui menciptakan dan mengelola segala sesuatu dengan ukuran, kadar dan waktu tertentu guna mencapai tujuan. Keyakinan itu akan mengantarkan kepada keadilan Ilahi. (M. Quraisy Shihab, 1996: 118). Firman Allah swt, surat al-Rahman (55) ayat 7 menyatakan:

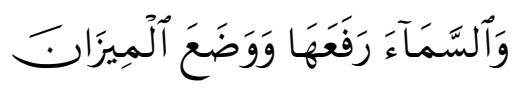

"Dan Allah telah meninggikan langit dan ia menegakkan neraca (keadilan)". (Q.S. Al-Rahman [55]: 7).

Keadilan di sini mengandung pengertian keseimbangan sunnatullah yang berlaku di seluruh langit.

Ketiga, adil dalam arti "perhatian terhadap hak-hak individu dan memberikan hak-hak itu kepada para pemiliknya". Lawan keadilan dalam pengertian ini adalah kezaliman. Murtadha Muthahhari (1992: 56) menamakan keadilan ini dengan keadilan sosial. Agar Individu-individu dalam masyarakat dapat meraih kebahagian dalam bentuk yang lebih baik, maka hakhak dan preferensi-preferensi individu itu, mesti dipelihara dan diwujudkan. Keadilan, dalam hal ini, bukan berarti mempersamakan semua anggota masyarakat, melainkan mempersamakan mereka dalam kesempatan mengukir prestasi.

Keempat, adil yang dinisbahkan kepada Ilahi. Adil di sini berarti memelihara kewajiban atas berlanjutnya eksistensi, tidak mencegah kelanjutan eksistensi dan perolehan rahmat sewaktu terdapat banyak kemungkinan untuk itu. Keadilan Allah swt pada dasarnya merupakan rahmat dan kebaikannya. Firman Allah swt yang terdapat pada surat Hud (11) ayat 6 menegaskan:

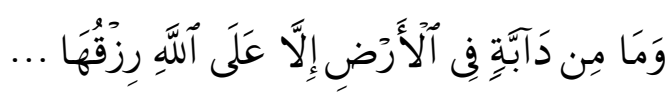

"Dan tidak ada suatu binatang melata pun di bumi ini melainkan Allah-lah yang memberi rizkinya ..." Binatang melata, pada ayat ini, berarti segenap mahluk Allah yang bernyawa...(Q.S. Hud [11]: 6).

Ayat lain yang menunjukkan hal yang sama adalah surat Fushilat (41) ayat 46:

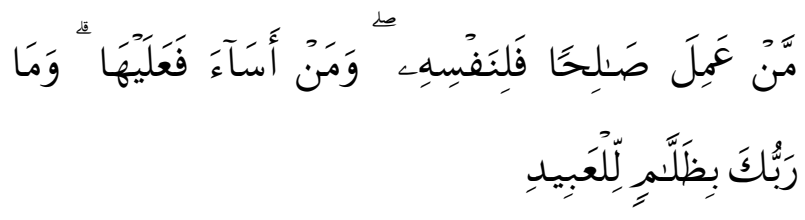

"Siapa yang beramal shaleh, maka akan dia terima untuk dirinya dan siapa yang berbuat jahatm, dia akan terima 
balasannya. Dan Tuhanmu tidak berlaku aniaya kepada hamba-hambanya". (Q.S. Fussilat [41]: 46).

Menurut Murtadha Muttahari (1992: 63), keadilan ilahi, merupakan persoalan yang menarik semua orang, melibatkan orang-orang desa yang buta aksara dan para filosuf yang pemikir. Oleh karena itu, keadilan Tuhan memiliki urgensi khusus, dan merupakan persoalan yang tiada taranya. Para teolog muslim tidak kunjung selesai memperbincangkan masalah tersebut. Syi'ah dan Mu'tazilah memandang keadilan sebagai prinsip ke dua di dalam ushuluddin (pokok-pokok agama).

\section{Perwujudan Keadilan Hukum Menurut Islam}

Sebagai hasil dari bahasan ini bahwa hukum adalah himpunan petunjuk hidup (perintah-perintah dan larangan-larangan) yang mengatur tata tertib dalam sesuatu masyarakat, dan seharusnya ditaati oleh anggota masyarakat yang bersangkutan, oleh karena pelanggaran petunjuk hidup tersebut dapat menimbulkan tindakan dari pihak pemerintah masyarakat itu. (E. Utrecht 1966: 13). Menurut (Siti Musdah Mulia, 2005: 302), hukum adalah aturanaturan normatif yang mengatur pola perilaku manusia. Hukum tidak tumbuh di ruang vakum (kosong), melainkan tumbuh dari kesadaran masyarakat yang membutuhkan adanya suatu aturan bersama. Hukum Islam oleh TM. Hasbi Ash Shiddieqy sebagaimana dikutip oleh Ismail Muhammad Syah (1992: 19) dirumuskan sebagai koleksi daya upaya para ahli hukum untuk menerapkan syari'at atas kebutuhan masyarakat. Dalam kaitannya dengan aspek hukum, maka keadilan hukum Islam bersumber dari Tuhan yang Maha Adil, karena pada hakikatnya Allah-lah yang menegakkan keadilan (qaiman bilqisth). Karenanya, harus diyakini bahwa Allah tidak berlaku aniaya (zalim) kepada hamba-hambaNya (Q.S. 10/Yunus: 449), setiap perbuatan manusia akan dipertanggung-jawabkan kepada-Nya pada hari keadilan (Q.S. 4/alNisa: 110).

Adil secara hukum dalam pengertian persamaan (equality), yaitu persamaan dalam hak, tanpa membedakan siapa; dari mana orang yang akan diberikan sesuatu keputusan oleh orang yang diserahkan menegakkan keadilan, sebagaimana dimaksud firman Allah Q.S. 4/al-Nisaa': 58:

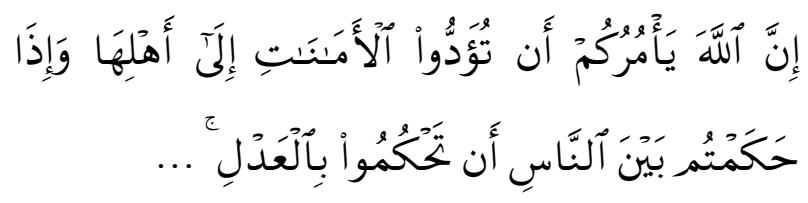

"Dan ...Apabila kamu memutuskan perkara di antara manusia, maka hendaklah engkau putuskan dengan adil". (Q.S. An-Nisa [4]: 58).

Ketegasan prinsip keadilan tersebut dijelaskan oleh ayat Al-Qur`an Q.S. 57/alHadid: 25 tersebut di atas. Kata mizan (keadilan) dengan hadid (besi). Besi adalah suatu benda yang keras, dan dijadikan sebagai senjata. Demikian pula halnya hukum dan keadilan harus ditegakkan dengan cara apapun, jika perlu dengan paksa dan dengan kekerasan, agar yang bersalah atau yang batil harus menerima akibatnya berupa sanksi atau kenistaan, sedangkan yang benar atau yang hak dapat menerima haknya. Muhammad Tahir Azhari, 2003: 117 - 124).

Dalam prinsip keadilan hukum, Nabi SAW menegaskan adanya persamaan 
mutlak (egalitarisme absolut, al-musawah almuthlaqah) di hadapan hukum-hukum syariat, tidak membedakan status sosial seseorang, apakah ia kaya atau miskin, pejabat atau rakyat jelata, dan tidak pula karena perbedaan warna kulit serta perbedaan bangsa dan agama. Di hadapan hukum semuanya sama. Konsep persaman yang terkandung dalam keadilan tidak pula menutup kemungkinan adanya pengakuan tentang kelebihan dalam beberapa aspek, yang dapat melebihkan seseorang karena prestasi yang dimilikinya. Akan tetapi kelebihan tersebut tidaklah akan membawa perbedaan perlakuan hukum atas dirinya.

Pengakuan adanya persamaan, bahkan dalam Al-Qur`an dinyatakan sebagai "pemberian" Allah yang mempunyai implikasi terhadap tingkah laku manusia, adalah bagian dari sifat kemuliaan manusia (al-karamah alinsaniyah), yang juga bagian dari ketetapan Tuhan (Q.S. 17/al-Isra: 70), yang berbunyi:

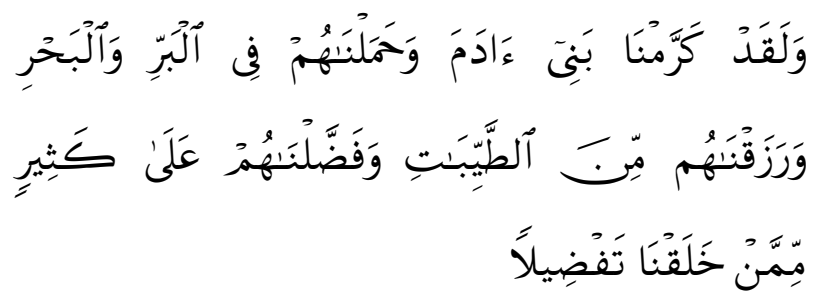

"Dan Sesungguhnya telah Kami muliakan anak-anak Adam, Kami angkut mereka di daratan dan di lautan[862], Kami beri mereka rezki dari yang baik-baik dan Kami lebihkan mereka dengan kelebihan yang sempurna atas kebanyakan makhluk yang telah Kami ciptakan". (Q.S. Al-Isra [17]: 70).
Martabat dan harkat manusia dalam pandangan Al-Qur'an adalah sebagai anugerah Allah SWT,. Oleh karena itu tidak ada satu kekuatan apapun yang dapat merusakkan dan menghancurkannya. Pengakuan ini memperkuat adanya kewajiban dan tanggungjawab manusia yang seimbang dalam kehidupan ini. Karenanya, keadilan hukum berarti pula adanya keseimbangan dalam hukuman terhadap kejahatan atau pelanggaran, hukuman seimbang atau setimpal dengan kejahatan atau pelanggaran yang dilakukan. Penegakan hukum secara adil dan merata tanpa pilih bulu adalah menjadi keharusan utama dalam bidang peradilan, walaupun berkaitan dengan diri sendiri, keluarga dekat, atau orang-orang yang memiliki pengaruh atau kekuasaan, (Didin Hafidhuddin, 2000: 215). Sebagaimana dikemukakan di dalam surat an-Nisa ayat 135.

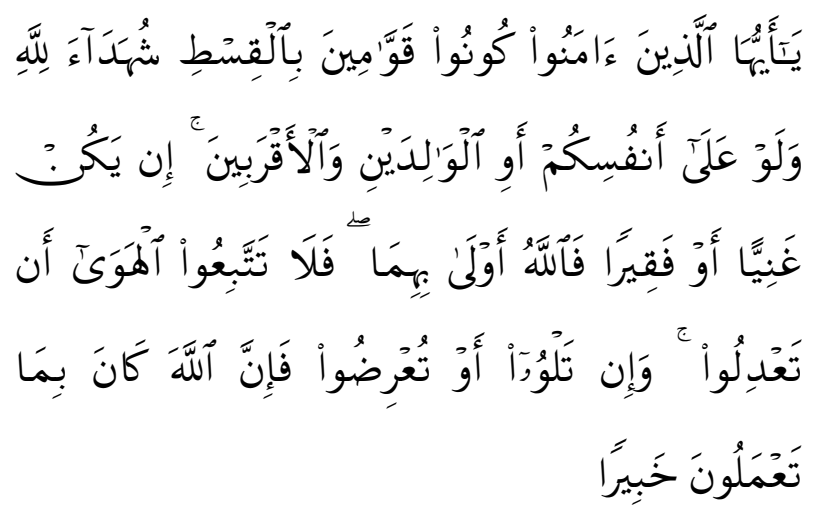

"Wahai orang-orang yang beriman, tetaplah beriman kepada Allah dan RasulNya dan kepada kitab yang Allah turunkan kepada Rasul-Nya serta kitab yang Allah turunkan sebelumnya. Barangsiapa yang kafir kepada Allah, malaikat-malaikat-Nya, kitab-kitab-Nya, rasul-rasul-Nya, dan hari Kemudian, Maka Sesungguhnya orang itu 
telah sesat sejauh-jauhnya". (Q.S. An-Nisa [4]: 135).

Dalam praktek ajaran Islam, suatu peristiwa setelah penaklukan kota Mekah, ada seorang perempuan keturunan suku Quraisy dari Bani Makhzum melakukan pencurian. Menurut ketentuan Islam, hukuman yang harus dijatuhkan terhadap pencuri adalah potong tangan (Q.S. 5/alMaidah: 38). Mengetahui betapa beratnya hukuman tersebut, maka salah seorang pemuka Quraisy menemui Usamah bin Zaid meminta agar Usamah menemui Nabi SAW untuk menyampaikan permohonan suku Makhzum ini kepada Nabi agar wanita tersebut diberi dispensasi, dibebaskan dari hukuman pidana tersebut. Mendengar permintaan Usamah ini, Nabi SAW. balik bertanya kepada Usamah, apakah mereka ini meminta syafa'at bagi seseorang dalam kejahatan yang telah jelas hukumannya dari Allah. Kemudian serta merta Nabi SAW. berdiri seraya memberikan penjelasan singkat: "Sesungguhnya kebinasaan umat sebelummu bahwa jika terjadi pencurian yang dilakukan orang dari golongan bangsawan, mereka dibebaskan tidak dihukum, tetapi jika pencurian dilakukan oleh orang lemah (rakyat biasa) mereka melaksanakan hukumannya, maka Nabi SAW mengucapkan sumpah, Demi Allah jika Fatimah anak Muhammad mencuri, niscaya aku potong tangannya.

Keadilan hukum dalam Islam tidak menyamakan hukuman di antara orang kuat dan orang lemah, tetapi memiliki persepsi lain yang belum pernah ada sebelumnya, dan tidak dapat disamakan dengan sistem hukum manapun sekarang ini, bahwa hukuman bisa menjadi lebih berat bila pelakunya orang besar, dan hukuman sesuai dengan tindakan pidana, maka haruslah hukuman itu menjadi lebih berat sesuai dengan kelas pelaku tindak pidana tersebut. Keadilan dalam hukum Islam membawa suatu prinsip yang belum pernah dikenal sebelumnya. Sebagian negara-negara di dunia sekarang tidak memberikan hukuman terhadap tindakan pidana yang dilakukan seorang kepala negara, karena hukum itu tidak mengandaikan terjadinya tindakan pidana dari seorang kepala negara. Para pembuat undang-undang menganggap pribadi kepala negara sebagai orang yang dilindungi dan tidak dapat disentuh oleh hukum. (Abdurrachman Qadir: 131 - 133). Para fuqaha telah sepakat bahwa para penguasa dan pemimpin tertinggi negara tetap bisa dikenakan hukum seperti halnya kebanyakan orang, tanpa perbedaan apapun. Jadi, tidak ada perbedaan antara pimpinan besar yang menjadi kepala negara dan orang biasa dalam perlakuan hukum. Kedudukannya sebagai kepala negara tidak dapat menyelamatkan dari ancaman hukuman bila terbukti bersalah.

Ilustrasi berikut dapat diungkap sebagai konsep/model konstitusi Islam ideal yang mengatur hak dan kewajiban berdasarkan keadilan. Di antara isi konsep institusi itu adalah (1) setiap orang berhak mendapat perlindungan bagi kebebasan pribadinya. (2) setiap orang berhak memperoleh makanan, perumahan, pakaian pendidikan dan perawatan medis. Negara harus mengambil semua langkah yang diperlukan untuk menyediakan fasilitas untuk itu sesuai dengan kemampuan. (3) setiap orang berhak mempunyai pikiran, mengemukakan pendapat dan kepercayaan selama ia masih berada 
dalam batas-batas yang ditetapkan oleh hukum. (4) semua orang sama kedudukannya dalam hukum. (5) semua orang dengan kemampuan yang sama berhak atas kesempatan yang sama, dan penghasilan yang sama atas pekerjaan yang sama, tanpa membedakan agama, etnis, asal-usul dan sebagainya (6) setiap orang dianggap tidak bersalah sampai akhirnya dinyatakan bersalah oleh pengadilan, dan beberapa hak dan kewajiban yang menyangkut beberapa aspek sosial, politik, ekonomi, pertahanan keamanan dan sebagainya. (Abdurrachman Qadir: 131 - 133).

Keadilan hukum menempatkan secara formal semua orang sama di hadapan hukum. Martabat dan kehormatan manusia dalam pandangan Al-Qur`an adalah anugerah Allah SWT. Oleh karena itu, tidak ada satu kekuatan pun yang dapat merusakkan dan menghancurkannya, kecuali sesuai dengan ketentuan yang telah diberikan Allah.

Dalam materi hukum, keadilan yang diterapkan adalah keadilan berimbang. Dalam bidang hukum pidana Islam, asas keberimbangan terlihat pada sanksi yang diberikan kepada pelaku kejahatan. Semakin tinggi kualitas kejahatan, semakin tinggi sanksi yang diberikan, dan semakin tinggi status sosial dan kedudukan seseorang dalam masyarakat, semakin berat hukuman yang dijatuhkan. Dalam bidang perdata juga berlaku prinsip keadilan berimbang. Perbandingan dan perbedaan porsi bagi ahli waris sebagaimana yang telah ditentukan oleh Al-Qur`an, adalah disesuaikan dengan perimbangan tanggungjawab yang dibebankan antara laki-laki dan perempuan. Sangat kelihatan, bahwa keadilan diterapkan dalam upaya menempatkan sesuatu pada tempat yang semestinya. Termasuk keadilan, adalah pengenaan denda atau hukuman atas orang-orang yang melanggar ketentuan-ketentuan agama, seperti seorang suami yang menzihar istrinya atau suami isteri yang melakukan hubungan seksual pada siang hari bulan Ramadhan. Kepada mereka dikenakan kifarat (semacam hukuman), yaitu memberi makan 60 orang fakir miskin, sedangkan bagi orang yang mengambil haji tamattu'; kepadanya dikenakan denda, yaitu dalam bentuk memotong seekor kambing sebagai dam.

Dari uraian di atas, penulis menyimpulkan bahwa keadilan sosial dalam aspek hukum ditandai dengan adanya persamaan semua orang dihadapan hukum, selain itu hukum ada di atas segalanya dan setiap orang dilindungi hak-haknya.

\section{KESIMPULAN}

Berdasarkan kajian singkat tersebut di atas dapat dirangkum sebagai berikut:

1. Keadilan dalam Islam paling tidak mencakup empat makna; keadilan dalam arti sama atau persamaan, keadilan dalam arti seimbang (proporsional), keadilan dalam arti memberikan hak kepada pemiliknya, dan keadilan Ilahi.

2. Keadilan diperintahkan kepada para Rasul dan amanat kepada manusia, sebagai pengemban keadilan dari Allah yang Maha Adil. 
3. Semua orang di mata hukum mesti diperlakukan secara adil tanpa ada perbedaan dari segi fungsi dan jabatan serta strata, walaupun memungkinkan bahwa semakin tinggi jabatan seseorang yang melanggar hukum akan diberi hukuman yang lebih berat. Sebaliknya orang yang kurang/tidak berperstasi di bidang ekonomi, berhak mendapat santunan di bidang ekonomi berhak mendapat santunan dari pemerintah Islam, baik dari harta zakat, atau lainnya

4. Para penguasa sebagai pemegang mandat dari Allah untuk menegakkan keadilan pada pemerintahannya dan rakyatnya.

\section{DAFTAR KEPUSTAKAAN}

Abd al-Baqi, Muhammad Fu'ad, 1987, alMu'jam al-Mufahras li Al-Fadh AlQur'an al-Karim, Bairut: Dar al-Fikr

Abdurrachman Qadir, Zakat Dalam Dimensi Mahdah dan Sosial

Al-Ashfahani, t.t., Mu'jam Mufradat alFadh Al-Qur'an, Dar al-Kitab al-Arabi

Al-Zuhaily, Wahbah, 1991, al-Tafsir alMunir, Jilid IX, Beirut, Dar al-Fikr

Depdikbud, 1990, Kamus Besar Bahasa Indonesia, Jakarta, Balai Pustaka
E. Utrecht, 1966, Pengantar dalam Hukum Indonesia, Jakarta: Balai Buku Ihtiar

Ismail Muhammad Syah, 1992, Filsafat Hukum Islam, Bumi Aksara, Jakarta

Khadduri, Majid, 1999, Teologi Keadilan Perspektif Islam, Surabaya, Risalah Gusti

Muthahari, Murtadha, 1992, Keadilan Ilahi, terjemahan, Agus Effendi, Bandung: Mizan

Muhammad Tahir Azhari, 2003, Negara Hukum: Suatu Studi tentang PrinsipPrinsipnya Dilihat dari Segi Hukum Islam, Implementasinya Pada Periode Negara Madinah dan Masa Kini, Jakarta: Prenada Media

Shihab, M. Quraisy, 1996, Wawasan Islam, Mizan: Bandung

Siti Musdah Mulia, 2005, “Pembaharuan Hukum Keluarga Islam di Indonesia", dalam Komaruddin Hidayat dan Ahmad Gaus AF (Editor), Islam Negara dan Civil Society, Paramadina (Anggota IKAPI), Jakarta. 